SHS Web of Conferences 17, 01021 (2015)

DOI: $10.1051 /$ shsconf/ 20151701021

(C) Owned by the authors, published by EDP Sciences, 2015

\title{
An Empirical Study of the Relationship between the Listed Company Stock Returns and the Credit Rating
}

\author{
Yong Wang, Xiaomin Chen \\ Department of Economics and Management, Harbin Institute of Technology, Harbin, China
}

\begin{abstract}
Based on the analysis of stock price changes motives, we select five indicators (market systemic risk, book-to-market ratio, net income per share, net profit growth rate and size of the company) from the factors which affect stock yields, introduce the variable-credit rating, construct a multi-factor model which is suitable for China's stock market, study the relationship between stock yields of listed companies and credit rating. It was found that stock yields are negatively related to credit risk, and listed companies with low credit risk will get higher stock returns in the future than those with high credit risk.
\end{abstract}

Keywords. listed company; stock returns; credit rating

\section{Introduction}

Nowadays with continuous development of the securities market and the more perfect operation mechanism, factors affecting stock yields are also changing. A correct understanding of the influence factors of stock yields is helpful to the securities market operation mechanism, and also helpful to the reasonable pricing of our country's stock.

Domestic and foreign scholars found that there is a certain relevance between the listed company stock yields and the company's credit rating, and Sun Maohui (2012) built a four-factor model to study the relationship between stock yields of listed companies and the companies' market systemic risk, credit risk, company size and book-to-market ratio, found that stock yields is negatively related to the credit risk factors during the inspection period, that is, the future stock returns of listed companies with low credit risk is higher than those with high credit risk, and the stock yields and credit risk are in the reverse change, which is contrary to the general rule in economics - "high-yield high-risk" $"$.

Dichev's (1998), Griffin's (1998), Campbell's (2008) and other studies show a negative correlation between future stock income and credit risk ${ }^{[2]}$. Sorensen (1980) regarded local government's debt in the United States as the sample, the cost of capital as the dependent variable, and regarded various economic variables that can measure solvency and the virtual variables that On behalf of the credit rating as independent variables, and add to the regression model that explains the cost of capital, found that even including all the variables to measure solvency, the credit rating can significantly affect the cost of capital ${ }^{[3]}$. Garlappi etc. (2008) did not find - there is a abnormal negative correlation between "credit risk and returns", neither positive correlation. M.J. Barron (2008) used the standard \& poor's data (from 1984 to 1992) to study the British common credit rating, credit rating change and credit announcement's effects on stock returns, and found 
that the credit rating downgrades has a negative effect on stock returns, and there is a positive correlation between positive credit announcement and stock returns, but either from the short or long term, there is no significant relationship between credit rating and stock returns ${ }^{[4]}$. Doron Avramov etc. (2009) did a further research to whether there is a negative correlation relationship between credit risk and stock returns, and within 3 months before and after the fall in the credit rating, there is a significant negative correlation relationship between credit risk and stock yields.

\section{Theoretical models and research methods}

Arbitrage Pricing (ATP) model is to analyze the relationship between the expected return and risk of securities, which is a multi-factor pricing model. ATP model is based on efficient market arbitrage, when there is unreasonable pricing in the market, rational investors will immediately arbitrage. According to ATP pricing theory, the return of securities $i$ in investment period can be expressed by linear function as follows:

$$
r_{i}=a_{i}+\sum_{j=1}^{k} b_{i j} F_{j}+\varepsilon_{i}, i=1,2,3 \cdots \mathrm{n}
$$

In above formula, ${ }^{r}$ is the return of securities $i$ in investment period, $F_{j}$ is the NO. ${ }^{j}$ public risk factor influencing stock returns, $a_{i}$ is the respected return of securities $i$ when all $F_{j}=0(j=1,2, \cdots k) ; b_{i j}$ is the sensitivity coefficient of securities $i$ to NO. $j$ public risk factor, ${ }^{\varepsilon_{i}}$ is random error.

On the basis of the above model, we establish six-factor linear model to study the relationship between stock returns and credit rating, and the regression model is established in this paper are as follows:

$$
R=\partial+\lambda_{1} \beta+\lambda_{2} \Delta E P S+\lambda_{3} \Delta B V P S+\lambda_{4} B D M+\lambda_{5} S I Z E+\lambda_{6} R A T I N G+\varepsilon
$$

In above model, $R$ denotes individual stocks yields, $\beta$ denotes market systemic risks, $\triangle B V P S$ denotes net earnings per share, $\triangle B V P S$ denotes net profit growth rate, $B D M$ denotes book-to-market ratio, $S I Z E$ denotes company size, in order to eliminate the influence of the dimension, in empirical analysis we choose natural logarithm Ln ( SIZE); RATING denotes company's credit rating, AAA is $1, \mathrm{AA}+$ is 2 , AA is 3 , in ascending order, the bigger the numerical value reflects the higher credit risk.

We choose 12 months' circulation market value weighted holding period yield value $\beta$, and this coefficient is the only index to measure market systemic risk; net earnings per share is one of the most important indicators of the annual report of listed companies, and the calculation formula of net income per share is:

net income per share = net income/final total equity; net profit growth is an important index to reflect long-term growth level of listed companies, and its formula: net profit growth rate $=$ (current net - net profit of the previous period) / net profit of the previous period; the company size is related to the company's resist- risks ability, and we choose company assets quantization scale; book-to-market ratio uses this formula: book value/market value ( $\mathrm{BE} / \mathrm{ME}$ ) = book value per share/stock market prices, the selected credit rating data of listed companies is the company's main annual credit rating data, but stock yield data is monthly yield, because of frequent fluctuations of stock gains, the annual return rate will not be able to actually reflect the change of stock returns. 


\section{Empirical analysis}

\subsection{Sample selection and data sources}

We select A shares on the Shanghai Stock Exchange and Shenzhen Stock Exchange as the original study sample, after eliminating ST, PT listed companies that cannot guarantee continued operation and listed non-financial companies with incomplete data, and acquire the final sample data including 196 listed companies in the empirical analysis. The 196 listed companies cover manufacturing industry, construction industry, pharmaceutical industry and integrated industry, and the data is comprehensive and fully representative.

Sample financial data is from RESSET financial database, and timeline is 2013; the data measuring systemic risk is rolling circulation market value weighted for 12 months from RESSET financial database - Bata - risk factor data in December 2013. Listed companies credit rating is from Fitch IBCA's corporate credit rating. Data from the websites of International Credit Rating Co., Ltd. of integrity, Shanghai Far East Credit Rating Co., Ltd., a joint Credit Rating Co., Ltd, New Century Credit Rating Company website and Dagong Global Credit Rating Co., Ltd.

\subsection{Empirical test and results analysis}

According to six-factor pricing model, the empirical results are summarized in table 1 and table 2 .

Table 1. Stock yields and the correlation coefficient of each index

\begin{tabular}{c|llllll}
\hline & $\begin{array}{l}\text { Book-to- } \\
\text { market } \\
\text { ratio }\end{array}$ & $\begin{array}{l}\text { Net profit } \\
\text { growth rate }\end{array}$ & Beta & $\begin{array}{l}\text { Net } \\
\text { earnings } \\
\text { per share }\end{array}$ & $\begin{array}{l}\text { Company } \\
\text { size }\end{array}$ & Credit rating \\
\hline $\begin{array}{l}\text { Pearson } \\
\text { Correlation }\end{array}$ & $-0.188^{* *}$ & 0.023 & $-0.512^{* *}$ & 0.031 & $-0.028^{*}$ & -0.014 \\
\hline $\begin{array}{l}\text { Significance } \\
\text { (one side) }\end{array}$ & 0.008 & 0.750 & 0.000 & 0.662 & 0.696 & 0.843 \\
\hline $\mathbf{N}$ & 196 & 196 & 196 & 196 & 196 & 196 \\
\hline Sig.(one side) & 0.004 & 0.375 & 0.000 & 0.331 & 0.002 & 0.422 \\
\hline $\mathbf{N}$ & 196 & 196 & 196 & 196 & 196 & 196 \\
\hline
\end{tabular}

Notes: $^{* *}$. above 0.01 shows significant correlation; *. above 0.05 shows significant correlation

Conclusion by table 1: credit risk and stock yields show a weak negative correlation relationship, which is inconsistent with "high-risk high-yield" rule. However, from the existing credit rating evaluation indexes we can see that $70 \%$ of them are determined by the company's financial indicators, and these financial indicators mainly includes the corporate profitability indicators, solvency indicators and sustainable growth ability indicators. Credit rating and these financial indicators are positively related, and the financial indicators also have positive effect to listed companies stock yields; on the other hand, from the point that a company stock price decides its stock returns, actively credit rating announcement is good information for the company, and its sure that the disclosure of the company's good information is in favor of the company's stock price. Therefore, credit risk and listed companies' stock yields show a negative correlation relationship, namely, the higher the credit risk of listed companies, the lower the stock yields.

Using the method of into law, we make a multiple linear regression analysis on all sample stock yields and the six indicators, the results are shown in table 2.

To analyze the regression results of table 2 , we can draw the following conclusions:

(1) On the whole, the effect of Beta, book-to- market ratio and net earnings per share of stock yields is more significant than other factors.

(2) Credit risk is negatively related to stock yields.

(3) There is no multicollinearity problem among 6 regression indexes. 
Table 2. Multiple linear regression of stock yields and six indicators (into law)

\begin{tabular}{l|llll}
\hline variable & coefficient & t & Sig. & VIF \\
\hline Book-to- market ratio & -0.100 & -1.552 & 1.051 & 1.100 \\
Net profit growth rate & 0.023 & 0.369 & 1.105 & 1.051 \\
Beta & -0.523 & -8.093 & 1.160 & 1.105 \\
Net earnings per share & 0.112 & 1.684 & 1.087 & 1.160 \\
Company size & -0.013 & -0.205 & 1.035 & 1.087 \\
Credit rating & -0.008 & -0.130 & 0.897 & 1.035 \\
\hline
\end{tabular}

\section{Conclusion}

In efficient capital market, investors' forecasts of future accounting earnings are reflected in stock yields, and only new information arrives to the market and changed the expectations of investors, the stock price will change, and then affects stock yields; good news and bad news can produce different expectations for the capital market, and the accounting information will affect investors' decision-making, then Improves the accuracy that investors judge stock returns. Based on theoretical analysis and empirical study of affecting factors of stock yields, we draw the following conclusions:

(1) Market systemic risk, book-to-market ratio and stock yields show a strong correlation, and net profit growth rate, company size, net earnings per share and stock yields show a weak but still significant correlation, where market systemic risk has the greatest impact on stock yields.

(2) Credit risk and stock yields show a weak negative correlation, ie, the higher the credit risk, the lower the stock yields, and vice versa. Even the credit rating has minimal Impact on stock yields among selected factors, and it still has certain explanatory power on stock returns.

When choosing factors, we just selected some relatively representative factors in our study, which may probably lead to certain deviation of the empirical results; and credit rating results cannot fully include all the actual market information, which increases the difficulty of stocks pricing when adding credit risk factors. With the further improvement of China's credit rating system and securities markets, credit rating will be important reference for the investors to make investment decisions, and stock price will be more reasonable in our country.

\section{References}

1. Campbell, J.Y., Hilscher, J., Szilagyi, J.: In search of distress risk [J]. Journal of Finance, 2008(63).

2. Guo Minhua. Credit Rating [M]. China Renmin University Press. p110-123.

3. Lynnette D. Purda*. Assessing credit or determining qualitity? The evolving role of rating agencies, 2011. 